\title{
Halfway to Sustainability: management lessons from community- based, marine no-take zones in the Mexican Caribbean
}

\section{Austin Ayer ${ }^{a, b}$, Stuart Fulton ${ }^{a}$, Jacobo Alejandro Caamal-Madrigala, Alejandro Espinoza-Tenorio ${ }^{\mathrm{b}, *}$}

a Comunidad y Biodiversidad A.C, Isla del Peruano 215, Lomas de Miramar, Guaymas, Sonora, México CP 85448

b El Colegio de la Frontera Sur (ECOSUR), Av. Rancho Polígono 2-A, Col. Ciudad

Industrial, Lerma Campeche, Campeche, México CP 24500

*Corresponding Author Tel. +52 9811273720 ext. 2411

E-mail addresses:

A. Ayer: ayeraustinm@gmail.com

S. Fulton: sfulton@cobi.org.mx

J. Caamal-Madrigal: jcaamal@cobi.org.mx

A. Espinoza-Tenorio: aespinoza@ecosur.mx

\begin{abstract}
Spatial closure regimes such as marine protected areas (MPAs) have emerged as a prominent tool in the effort to balance ecosystem health and fishery productivity. As MPAs have proliferated, the conservation community has begun to supplement traditional biological metrics with social and community considerations in the way it seeks to manage and evaluate such tools. To assess management outcomes and opportunities for a network of community-based, marine no-take zones (NTZs) in the Mexican Caribbean, semi-structured interviews were carried out with fishers and key management stakeholders. Findings indicate that the community-based management strategy has inherent tradeoffs between community engagement and conservation potential. Managers have succeeded in fostering high levels of community support for the initiative, but significant challenges remain, most notably the high presence of illegal fishing within NTZs. Successes and challenges of the community-based management strategy are documented and evaluated within a fisheries resource management framework. As the NTZ network undergoes legal renovation following the completion of its initial five-year term, this work serves as an important resource for both reflection on, and adaptation of, the community-based NTZ management regime.
\end{abstract}

Keywords: No-take zone; Marine protected area; Community-based management; Fisheries resource management; Fisher perceptions; Lobster fishery 


\section{Introduction}

\subsection{Community-based no-take zones}

In response to the degradation of marine ecosystems, marine protected areas (MPAs) have emerged as one of the most popular and fastest growing marine conservation strategies [1,2]. MPAs encompass a broad range of management regimes and realities, including areas fully closed to extractive activities known as no-take zones (NTZs) [3,4]. NTZs confer a greater degree of protection than other forms of MPAs, and are more effective at restoring fish biomass and ecosystem health than partially-protected MPAs [5,6]. In addition to well-documented biomass increases within and immediately around NTZs $[7,8]$, sustainable fishery management is often cited as a primary NTZ motivation. Emigration of mature fish from protected areas to fishing grounds (spillover) and the export of eggs or larvae from protected breeding populations are most often cited as ameliorating benefits to affected fisheries $[9,10]$.

As NTZs have proliferated with variable success, certain management trends have emerged, such as the importance of stakeholder inclusion and the failure of many top-down conservation initiatives [11-13]. These ideas have increased the emphasis placed on the social factors involved in successful NTZ deployment, contributing to the promotion of the community-based NTZ as a bottom-up management strategy more likely to achieve sustained success [14-16]. Communitybased NTZs seek to reduce stakeholder conflict by involving affected communities in site management. In addition to confronting compliance and surveillance issues that can frustrate larger, top-down efforts $[17,18]$, community-based NTZs can account for site-specific political, socioeconomic, and ecological context [19] and foster ownership and pride within the community [20].

The prominence of community-based management has begun to affect the way NTZs are evaluated. While the performance of NTZs has traditionally been assessed using biological metrics, increasing awareness of the importance of social factors on the success of marine conservation has supported the implementation of complementary socioeconomic evaluation strategies [21,22]. Indeed, it has been found that social factors are linked to, and sometimes even deterministic of, an MPA's long-term biological success or failure [23-25].

Fishers' inherent interest in NTZ design and implementation, along with their ability to heavily influence management success via compliance (or lack thereof) $[26,27]$, make their perceptions of NTZs especially relevant to managers. While social data such as perceptions are rarely objective, their influence on behavior, and thus tangible conservation outcomes, makes them a crucial piece of information $[22,28,29]$. Fishers' perceptions are fundamental to the social acceptance of NTZs, and thus their ability to achieve desired conservation goals [29,30]. With this in mind, many have called for studies examining the perceptions of fishers toward MPAs [2,28], although such empirical examinations are still lacking $[2,24,30]$.

\subsection{Biosphere Reserves Sian Ka'an and Banco Chinchorro}


Designated a Biosphere Reserve in 1986 and a UNESCO World Heritage Site in 1987, Sian Ka'an Biosphere Reserve (SKBR) encompasses 528,147 ha along the east coast of the Mexican state of Quintana Roo. Approximately 28\% of this territory is marine, including a 110-km segment of the Mesoamerican Barrier Reef System and two large bays: Ascensión Bay and Espíritu Santo Bay (Figure 1).

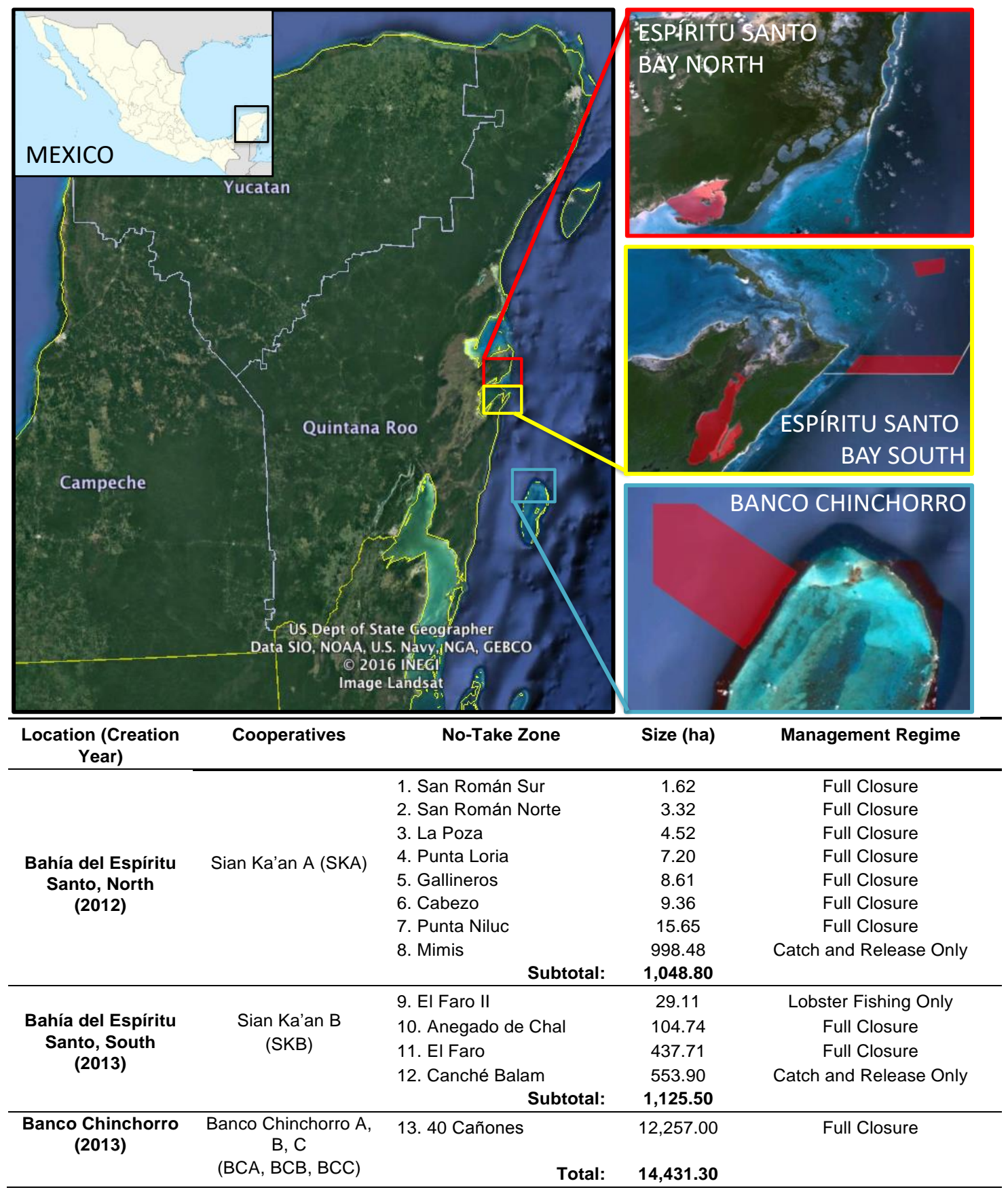

Figure 1. Study Sites. A network of 13 community-based NTZs (highlighted) established in Quintana Roo, México in 2012-2013. 
Three fishing cooperatives currently operate entirely within SKBR. Caribbean Spiny Lobster (Panulirus argus) supports the most important fishery, but a variety of finfish species are also marketed. Lobster fishing rights are granted to cooperatives in the form of exclusive and geographically-defined concessions, a type of Territorial Use Rights Fishery (TURF) [31]. SKBR fishers rely exclusively on free diving and the use of lassos or hand nets to capture lobster. Casitas cubanas, artificial shelters made of concrete [32], are employed in addition to reef diving. All SKBR cooperatives use a campo system, in which part or all of the cooperative's concession is divided into distinct parcels, or campos, which are then distributed among fishers. While fishers cannot legally own their campos, they own the casitas deployed within them, and thus exercise exclusive harvesting rights within the parcels [33]. In addition to commercial fishing, recreational fly-fishing tourism is an important income source for some SKBR communities.

The false coral atoll of Banco Chinchorro lies $30 \mathrm{~km}$ east of the Caribbean coast of Quintana Roo, and constitutes part of the Mesoamerican Barrier Reef System. Declared a Biosphere Reserve in 1996, Banco Chinchorro Biosphere Reserve (BCBR) encompasses 144,360 ha of marine protected area [34]. Three cooperatives have concessions to fish within the reserve. P. argus supports the most important fishery, but queen conch (Lobatus gigas) and a variety of finfish species, including deep-water snapper, are also commercially relevant. While certain core areas of BCBR (2,587 ha) are designated as permanent NTZs, the majority $(>95 \%)$ of the reserve is open to regulated cooperative fishing. Fishing techniques within BCBR consist of free diving with lassos (lobster) and spear guns or bottom fishing rigs (finfish).

\subsection{Community-based NTZs in the Mexican Caribbean}

The General Sustainable Fisheries and Aquaculture Law (2007), and more specifically rule NOM-049 (2014), described for the first time the Mexican government's authority to create refuge zones for the conservation of fishing resources within federal waters. In 2010, Mexican non-governmental organizations (NGOs), with support from relevant government agencies, approached leaders from a group of fishing cooperatives with the goal of establishing a series of communitybased NTZs within the cooperatives' concessions. The motivations for NTZ creation were to permit declining fishing stocks to rebound, to increase biomass and diversity of both target and non-target species in and around the NTZs, and to work toward the NGOs' established goal of protecting $20 \%$ of the state's coastal waters within NTZs [35]. The potential use of NTZs in sustainable tourism initiatives as a means of income-diversification was also an important factor for both NGOs and cooperatives.

The NGOs emphasized a bottom-up, participatory approach to NTZ design, citing community led surveillance and citizen-science biological monitoring as core tenets of their co-management strategy. Through a series of workshops, fishers were introduced to the concept of NTZs, and site suggestions were solicited from cooperative members. While scientists conducted field surveys and provided suggestions for biologically important sites, the ultimate decision on NTZ size, 
quantity, and location belonged to the cooperatives, and can thus be deemed a semiopportunistic approach to NTZ design. During the planning stages, fishers in participating SKBR cooperatives were found to be supportive of the NTZ initiative and its leaders while expectant of benefits. Major concerns were that illegal fishers would benefit disproportionately from the program, and that economic benefits for cooperative fishers were uncertain [18]. Finally, between November 2012 and September 2013, 13 NTZs within the concessions of five cooperatives were closed to extractive activities for a period of five years (Figure 1), at which point their renewal and/or adaptation would be subject to further study and ongoing community support.

With the renovation process for the Sian Ka'an and Banco Chinchorro NTZs occurring in 2017-2018, this work seeks to understand, within an interdisciplinary fisheries resource management framework [36], the performance of the community-based management process thus far, and to provide suggestions for improvement. Additionally, the stakeholder perceptions identified here will provide managers with the type of information cited as crucial for successful, adaptive NTZ management [28]. By illuminating which management actions are generating or undermining community support for the NTZ program, the lessons drawn from the data presented here can be used to improve the likelihood of successful outcomes in future community-based conservation initiatives.

\section{Materials and methods}

\subsection{Fishers' perceptions of NTZs}

A series of open and closed-ended questions were designed to assess fishers' perceptions of NTZs, their management, and their effects on the local fishery. Between October 2016 and February 2017, 86 semi-structured, face-to-face interviews [37] were carried out with cooperative members and non-member workers from four cooperatives in their respective fishing camps or cooperative headquarters (Table 1). Prior to the interview, respondents were informed of the anonymous nature of their responses and given the option to decline any question they didn't feel comfortable answering. Interviews were conducted in Spanish and generally lasted between 15 and 30 minutes. Detailed notes were taken on site and later transcribed into digital form.

Responses to interview questions that utilized a numerical scale were either grouped into equivalent-sized categories representing, for example, low, medium, and high responses, or were averaged across cooperatives to facilitate statistical comparisons between groups. Responses to open-ended questions were analyzed to identify a set of discrete themes that encompassed all responses. Responses were then individually coded in Microsoft Excel for the themes they contained. Data from closed-ended or categorical questions are represented as frequencies of the response values. Where applicable, statistical tests were applied to the data to confirm the significance of response differences between groups. 
Participatory observation was also employed as a means of building rapport with the fishers and gaining a better understanding of local context. Specifically, the interviewer lived and shared meals with the fishers in each cooperative for between 7 and 15 days, participated in daily fishing trips, and attended and assisted in workshops and presentations given by fisheries managers and scientists in the fishing camps.

\subsection{Key stakeholder interviews}

Once all interview data had been analyzed, preliminary results, along with a short list of guiding questions on the biophysical, socioeconomic, and governance context of the region, were presented to six key NTZ management stakeholders, including representatives of government, NGOs, and the academic sector (Table 1). After allowing stakeholders to review the data and consider the guiding questions, semi-structured interviews lasting approximately 30 minutes were carried out either face-to-face or over video call. Stakeholder responses were organized according to the three strands of protected area assessment described by Ervin: design, management processes, and ecological integrity [38] (Table 3). The resulting framework was used to characterize the strengths and challenges of the NTZ initiative, as well as to guide and contextualize an assessment of their performance to date.

\begin{tabular}{|c|c|c|c|c|c|c|}
\hline Interview Code & Cooperative & Members & $\begin{array}{c}\text { Members } \\
\text { Interviewed }\end{array}$ & $\begin{array}{c}\text { Percent } \\
\text { Interviewed }\end{array}$ & $\begin{array}{c}\text { Workers } \\
\text { Interviewed }\end{array}$ & $\begin{array}{c}\text { Total } \\
\text { Interviewed }\end{array}$ \\
\hline F-SKA & Sian Ka'an A & 20 & 14 & 70 & 8 & 22 \\
\hline F-SKB & Sian Ka'an B & 26 & 19 & 73 & 2 & 21 \\
\hline F-BCA & Banco Chinchorro A & 28 & 14 & 50 & 3 & 17 \\
\hline \multirow[t]{2}{*}{ F-BCB } & Banco Chinchorro B & 33 & 24 & 73 & 2 & 26 \\
\hline & Total & 107 & 71 & 66 & 15 & 86 \\
\hline Interview Code & \multicolumn{2}{|c|}{ Stakeholder Organization } & \multicolumn{4}{|c|}{ Organization Description } \\
\hline S-1 & \multicolumn{2}{|c|}{ CONAPESCA } & \multicolumn{4}{|c|}{$\begin{array}{l}\text { National Commission for Aquaculture and Fisheries; responsible } \\
\text { for enforcement of NTZs discussed here }\end{array}$} \\
\hline S-2 & \multicolumn{2}{|c|}{ CONANP (SKBR) } & \multicolumn{4}{|c|}{$\begin{array}{c}\text { National Commission for Natural Protected Areas; responsible } \\
\text { for greater Sian Ka'an Biosphere Reserve }\end{array}$} \\
\hline S-3 & \multicolumn{2}{|c|}{ CONANP (BCBR) } & \multicolumn{4}{|c|}{$\begin{array}{l}\text { National Commission for Natural Protected Areas; responsible } \\
\text { for greater Banco Chinchorro Biosphere Reserve }\end{array}$} \\
\hline S-4 & \multicolumn{2}{|l|}{ ECOSUR } & \multicolumn{4}{|c|}{ University Fisheries Research Department } \\
\hline S-5 & \multicolumn{2}{|c|}{ Alianza Kanan Kay } & \multicolumn{4}{|c|}{$\begin{array}{c}\text { Multi-sectoral network involved in NTZ management; includes } \\
\text { government, NGOs, and fishers }\end{array}$} \\
\hline S-6 & \multicolumn{2}{|c|}{ Comunidad y Biodiversidad } & \multicolumn{4}{|c|}{ NGO involved in NTZ management } \\
\hline
\end{tabular}

Table 1. Distribution of interviews carried out with 86 members of four fishing cooperatives and six key management stakeholders

\subsection{Fisheries resource management framework}

Acknowledging that fisheries are complex entities comprising biological, social, and political components, an interdisciplinary fisheries resource management (FRM) framework proposed by Nielsen and Holm [36] was adapted 
and employed as a tool for the modeling of NTZ management and the NTZ program's role within the greater fishery (Figure 2).

The original framework represents a generic fishery as comprising a social system (fishers) that interacts with a natural system (fish populations) under external influences. In practical terms, the authors distinguish between four functions of a management system: 1) Diagnostics: a measurement tool that allows the manager to distinguish between different states of the fishery system;2) Objectives: meaningful and unambiguous goals that guide intervention based on diagnostic results; 3 ) Intervention: a system that allows shifting the fishery system between states; 4) Policy-making: An important tool when diagnostics are uncertain, intervention mechanisms insufficient, and objectives non-committal.

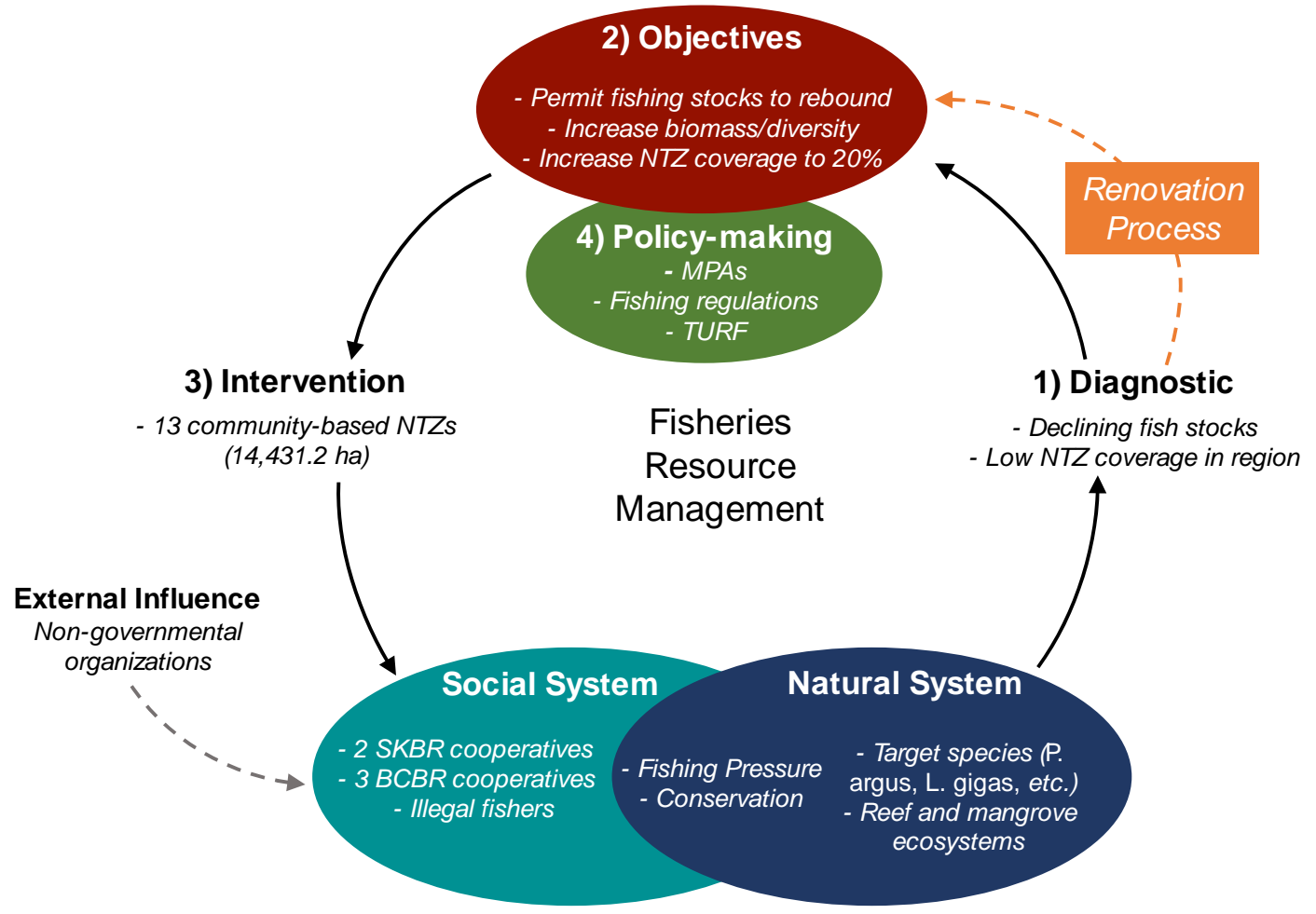

Figure 2. A Fisheries resource management feedback loop imposed as a control mechanism on a fishery (bold), in this case a network of community-based NTZs established in a Mexican Caribbean fishery (italics) (Modified from Nielsen and Holm, 2007).

It has been suggested that one facilitating factor of major fisheries management crises is the lack of a defined evaluation procedure and the lack of a capacity for systemic learning [36]. Inversely, then, it can be hoped that successful evaluative modeling of FRM can facilitate successful management and contribute to a sustainable fishery. 


\section{Results}

\subsection{NTZ objectives and implementation}

A majority of fishers from all cooperatives identified increased fishing production as a primary NTZ objective. Fishers also identified reproduction or recuperation of depleted fishing stocks, conservation for the future (working within a sustainable fishery), and opportunities for tourism development as important motivating factors (Figure 3). Accordingly, when fishers were asked to provide factors that led to the selection of specific NTZ sites for protection, a majority of responses cited natural or biological factors such as species abundance, reproduction sites, and reef formations. However, a significant minority of respondents from each cooperative also explained that certain NTZ sites were chosen simply because they weren't valuable fishing grounds, and therefore wouldn't affect fishers' interests upon being set aside for conservation. In a testament to the participatory nature of the NTZ design process, very few fishers $(0-6 \%)$ held the impression that scientists or managers made the ultimate decision on NTZ placement.

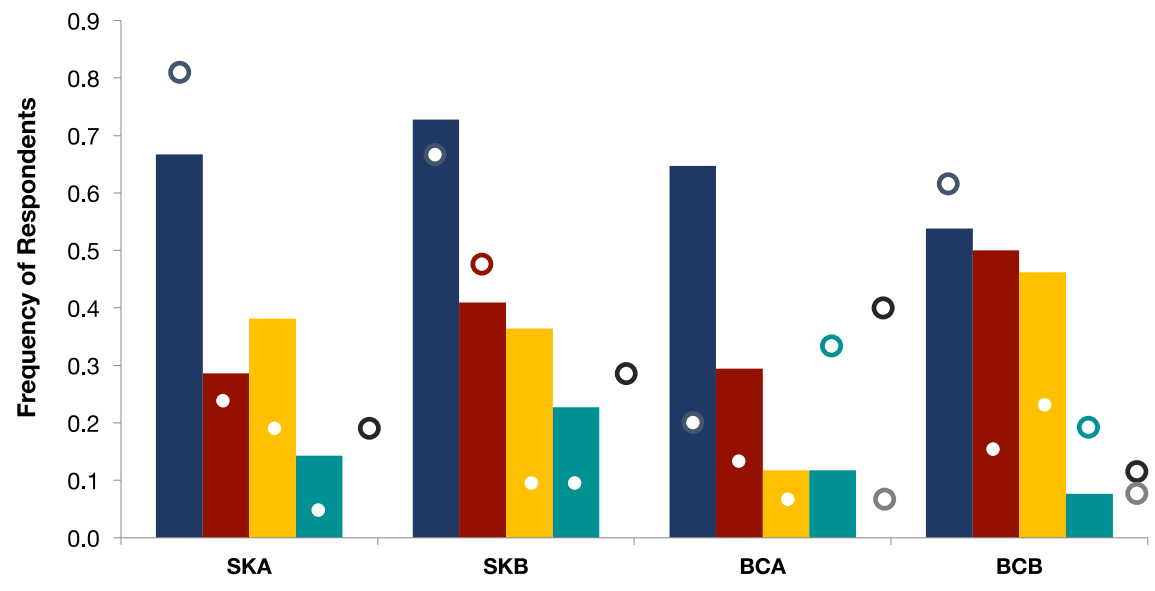

\begin{tabular}{|c|c|c|c|}
\hline Increased fishing production & Stock reproduction/recuperation & Sustainability/conservation & Tourism \\
\hline Site Selection Factors: & & & \\
\hline
\end{tabular}

Figure 3. Fishers' perceptions of the objectives of NTZ creation (columns) and reasons for NTZ site selection (circles). Values are frequencies of respondents, by cooperative, that identified a certain objective or site selection factor.

Regarding NTZ implementation, a strong majority of fishers from all cooperatives felt that they had been included in the process $(\mathrm{SKA}=100 \%, \mathrm{SKB}=$ $90 \%, \mathrm{BCA}=81 \%, \mathrm{BCB}=71 \%$ ) and reported having participated in the NTZ workshops and presentations held in their communities (SKA $=100 \%$, SKB $=94 \%$, $\mathrm{BCA}=88 \%, \mathrm{BCB}=96 \%$ ).

Fishers were asked whether they felt they knew the individuals and organizations that worked with them to create NTZs, and to rate the 
trustworthiness of these management partners on a scale of 1-5 (Figure 4). A ranked one-way ANOVA (Kruskal-Wallis) found significant response differences among the four cooperatives $(\mathrm{p}<.0001)$, and multiple pairwise analyses found the two SKBR cooperatives (mean SKA $=4.76$, mean SKB $=4.77$ ) to form a statistically distinct population from the two $\mathrm{BCBR}$ cooperatives (mean $\mathrm{BCA}=3.64$, mean $\mathrm{SKB}=$ $3.42)(p<.02)$. The lower levels of trust in BCBR seem to stem in part from the authorities' inability to effectively control illegal fishing in the NTZs and the greater reserve: "The problem is that [the authorities] haven't fulfilled what they said they were going to do... What purpose does an NTZ serve without people to enforce it?" (F$\mathrm{BCB})$.

Across all cooperatives, management actions cited as engendering stronger trust and confidence included having worked with the fishing communities for a long time, making frequent visits to the fishing camps, explaining the purposes and results of NTZs in clear and simple terms, and providing educational and training opportunities to fishers (for example, scientific SCUBA diver training).

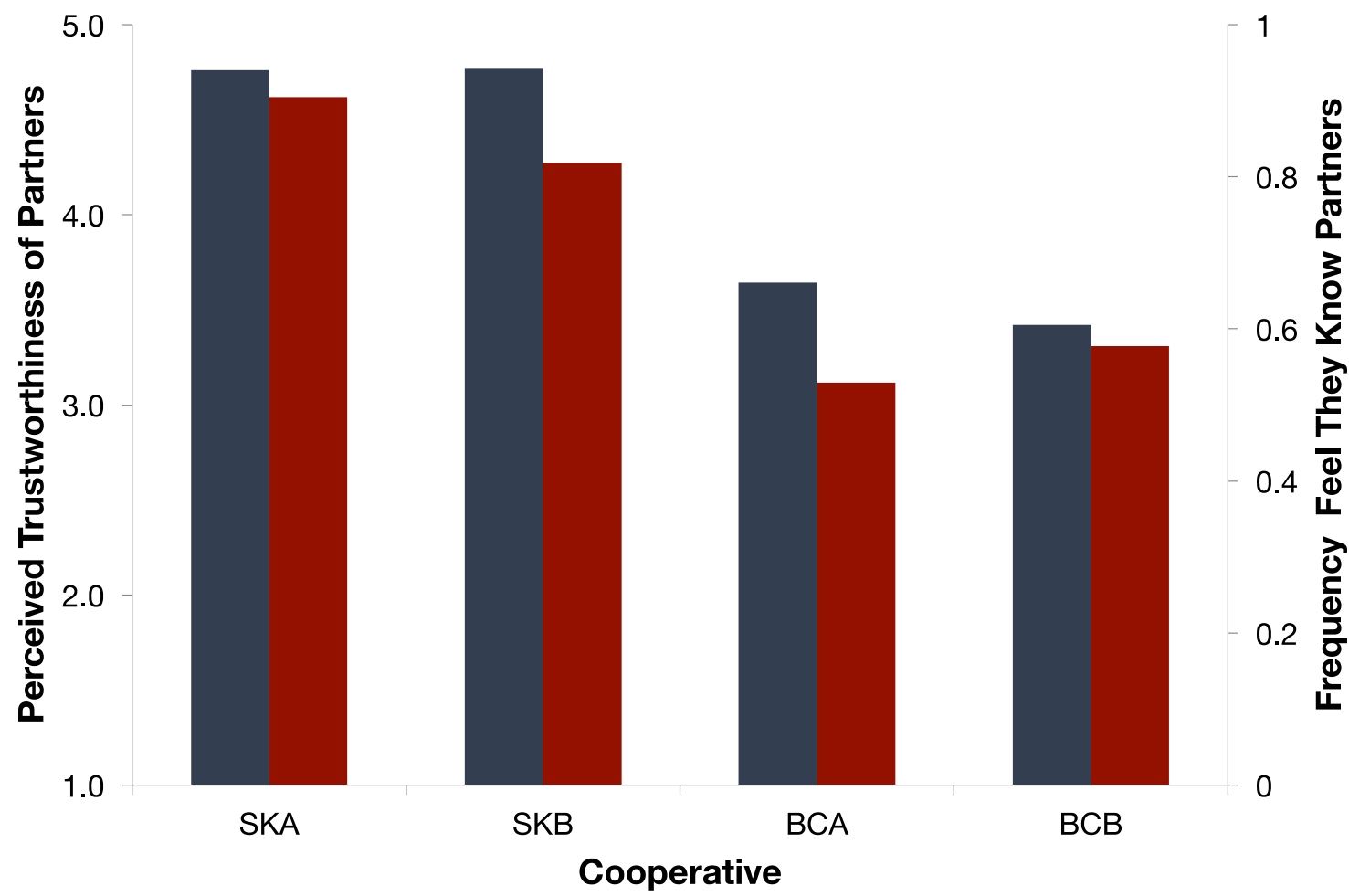

Figure 4. Fishers' relationship with NTZ management partners. Primary y-axis: perceived trustworthiness of NTZ management partners. Secondary-y axis: Frequency of fishers who feel they know their NTZ management partners.

\subsection{Enforcement}

Fishers rated the effectiveness of the current NTZ surveillance/enforcement system, and their responses were divided into three equally sized categories 
representing low, medium, and high levels of confidence in the enforcement regime (Figure 5a). A Kruskal-Wallis test again found significant differences between the populations ( $\mathrm{p}<.0001)$, and multiple pairwise analyses again separated the populations into two statistically-separate groups representing the SKBR and BCBR cooperatives, respectively $(\mathrm{p}<.0001)$.

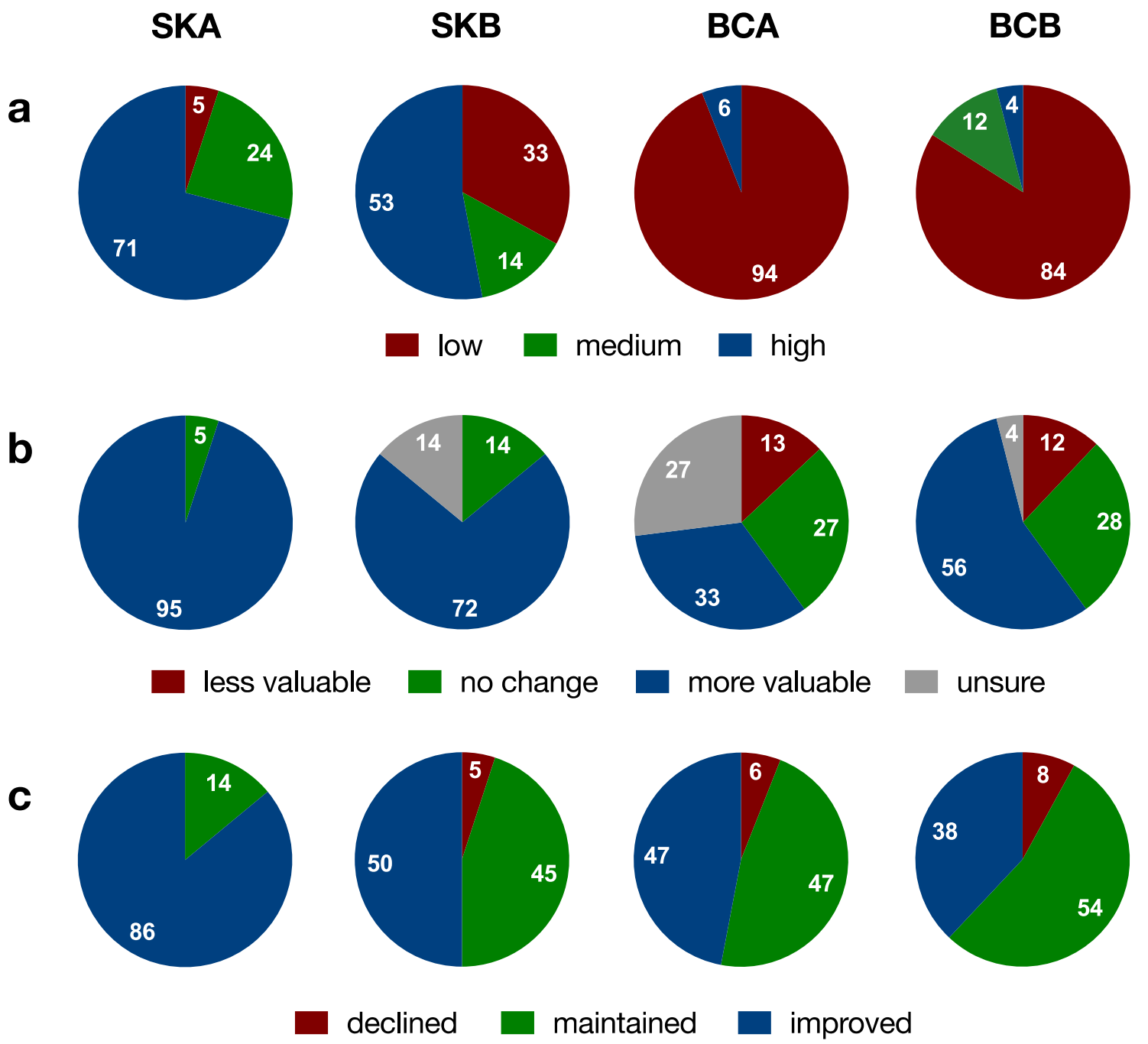

Figure 5. (a) Fishers' levels of confidence in the current NTZ surveillance/enforcement system; (b) Fishers' perceived change in value of NTZ sites since protection; (c) Fishers' perceived change in overall fishing production since NTZ establishment.

Fishers described known instances of illegal fishing within NTZs (Table 2a). Mutually exclusive categories of illegal fishers included poachers (non-cooperative fishermen), cooperative fishers (members of the cooperative whose concession contains the NTZ), delayed compliers (cooperative members, but only during the time period just after NTZ establishment), tourists, and members of other fishing cooperatives. BCBR fishers reported drastically higher levels of illegal fishing $(92 \%$, $94 \%)$ than SKBR fishers $(19 \%, 45 \%)$, with poachers being the most commonly observed illegal fisher. 


\begin{tabular}{rcccc}
\hline \multicolumn{1}{c}{ Cooperative } & SKA & SKB & BCA & BCB \\
\hline a) Observed Illegal Fishing & $19 \%$ & $45 \%$ & $94 \%$ & $92 \%$ \\
Poachers & $5 \%$ & $32 \%$ & $94 \%$ & $88 \%$ \\
Cooperative fishers & - & $9 \%$ & $12 \%$ & $15 \%$ \\
Delayed compliers & $5 \%$ & $9 \%$ & - & - \\
Tourists & - & - & $18 \%$ & - \\
Other cooperatives & $10 \%$ & - & - & - \\
\hline b) Factors affecting production & & & & \\
Weather/natural phenomena & $52 \%$ & $64 \%$ & $41 \%$ & $38 \%$ \\
Other sustainable practices & $48 \%$ & $36 \%$ & $47 \%$ & $35 \%$ \\
NTZs & $48 \%$ & $32 \%$ & $6 \%$ & $12 \%$ \\
Illegal fishing & - & - & - & $15 \%$ \\
Fishing pressure & - & - & - & $8 \%$ \\
Unorganized management & - & - & - & $4 \%$ \\
\hline Fishing production & $80 \%$ & $47 \%$ & $83 \%$ & $87 \%$ \\
Tourism & $35 \%$ & $76 \%$ & $8 \%$ & $13 \%$ \\
\hline Perceive economic benefit & $95 \%$ & $85 \%$ & $8 \%$ & - \\
Payment for work with NGOs & $15 \%$ & $18 \%$ & - & - \\
\hline d) Support NTZ renewal & $100 \%$ & $100 \%$ & $100 \%$ & $96 \%$ \\
\hline e) Support NTZ expansion & $44 \%$ & $47 \%$ & $24 \%$ & $20 \%$ \\
\hline
\end{tabular}

Table 2. (a) Reported knowledge of illegal fishing; (b) Fisher-identified factors that have most affected overall fishing production; (c) Perceived economic benefits conferred by NTZs; (d) Levels of fisher support for renovation and hypothetical expansion of NTZs.

\subsection{NTZ effects on fishery}

Fishers described how the value of NTZ sites had changed in the years since their establishment (Figure 5b). While respondents across all cooperatives were most likely to report an increase in site value, BCBR fishers were less likely to perceive that NTZ sites had improved and more likely to perceive a decline in site value than SKBR fishers.

Fishers were asked how overall fishing production in their concessions had changed in the years since NTZ establishment (Figure 5c). It was emphasized that the question was not intended to assess how NTZs had affected production, but rather to gauge the general trend of fishery productivity.

Fishers then identified the factors they perceive to have most influenced whichever production trend they identified (Table $2 \mathrm{~b}$ ). Regardless of perceived production trend, fishers were reluctant to attribute strong influence to NTZs. Across cooperatives, weather and other sustainable practices were assigned more influence over fishing production than NTZs. Other sustainable practices describes any sustainable management practice other than NTZs, and includes the change from lethal to non-lethal lobster capture methods and adherence to laws regarding the closed season and the capture of undersized or egg-bearing lobsters. Even in cooperative SKA, with the most positive outlook on both NTZ efficacy and production trends, only $48 \%$ of fishers expressed belief that NTZs had influenced 
the perceived increase in fishing production. Among BCBR respondents, only $6-12 \%$ of fishers believed the NTZs to have affected fishing production.

The survey sought to determine whether NTZ implementation had affected overall fishing effort or strategy among cooperative fishers. Such effects were found to be limited, with a minority of fishers reporting having increased their fishing pressure in areas around NTZs to take advantage of a perceived spillover effect (SKA $=17 \%, \mathrm{SKB}=7 \%, \mathrm{BCA}=0 \%, \mathrm{BCB}=12 \%$ ). In Sian Ka'an, this tendency is influenced by the campo system of fishing, which directs and limits where cooperative members can fish.

\subsection{Renovation considerations}

A majority of respondents from all cooperatives believed that NTZs confer an economic benefit to fishers (Table 2c). Specific sources of financial gain identified included fishing production, tourism, payment for work with NGOs (for example, employment of fishers as scientific divers during biological monitoring), and government financial support provided as a condition of NTZ creation.

\begin{tabular}{|c|c|c|}
\hline & Strengths & Challenges \\
\hline Design & $\begin{array}{l}\text { 1. Complements existing regulatory zoning (S- } \\
1,3,4,5,6) \\
\text { 2. Allows for overlapping enforcement } \\
\text { jurisdiction (S-3,5). } \\
\text { 3. Fishermen actively involved in process (S- } \\
\text { 1,4,5,6) } \\
\text { 4. Educates community }(S-1,2,3,4,5)\end{array}$ & $\begin{array}{l}\text { 1. Some NTZs in areas of little } \\
\text { ecological/fishery value (S- } \\
1,2,4) \\
\text { 2. NTZs within already protected } \\
\text { areas (S-2) }\end{array}$ \\
\hline $\begin{array}{l}\text { Management } \\
\text { Processes }\end{array}$ & $\begin{array}{l}\text { 1. Continued NGO involvement }(S-5,6) \\
\text { 2. Community ownership of NTZs }(S-6)\end{array}$ & $\begin{array}{l}\text { 1. Lack of enforcement (S- } \\
1,2,3,4,5,6) \\
\text { 2. Community apathy hinders } \\
\text { success (S-3) }\end{array}$ \\
\hline $\begin{array}{l}\text { Ecological } \\
\text { Integrity }\end{array}$ & $\begin{array}{l}\text { 1. Protects spawning sites }(S-1,4,6) \\
\text { 2. Protects reef habitat }(S-3,6)\end{array}$ & $\begin{array}{l}\text { 1. Some NTZs in areas of little } \\
\text { ecological/fishery value (S- } \\
1,2,4)\end{array}$ \\
\hline
\end{tabular}

Table 3. Management stakeholder-identified strengths and challenges of the communitybased NTZ model implemented in Quintana Roo, organized according to the three strands of protected area assessment described by Ervin (2003).

Fishers were nearly unanimous in their support for the renovation of existing NTZs, but were less supportive of a hypothetical NTZ expansion, with SKBR fishers more supportive of expansion than their BCBR counterparts (Table $2 \mathrm{~d}$,e). Across cooperatives, fishers cited a small and already restricted fishing area as justification for their lack of support for expansion. BCBR fishers also explained that without proper enforcement, an expansion of NTZs would only hurt cooperative fishermen and benefit poachers: "No one is going to want more [NTZs]. If we can't care for the ones we already have, why establish more?" (F-BCA). "If surveillance existed, we wouldn't need NTZs at all, because the cooperatives respect the closed season and size restrictions, it's the poachers who don't." (F-BCB). 


\section{Discussion}

\subsection{Potential of community-based NTZs}

As with any conservation measure, and especially given fisheries' status as complex, non-standard entities [36], it is important to have clear ideas about the purpose and potential of NTZs. Management stakeholders identified the protection of reef habitat and commercially relevant spawning sites as strengths of the NTZs discussed here, but expressed concern over the protection of certain low-value sites (Table 3). Indeed, fisher interviews revealed the common tendency to cede fishing ground of little value to the NTZ initiative, with $12-40 \%$ of each cooperative conceding that the chosen NTZ sites had little or no value (Figure 3). It is important to note that most NTZs discussed here have shown some level of biological recovery when compared to non-protected control sites, with those gains concentrated in NTZs with suitable habitat for target species $[39,40]$. Additionally, the protection of "less-valuable" sites within NTZs may be important for developing social acceptance of a new management tool. While a certain amount of give and take between scientists and local resource users is to be expected, and encouraged, in any community-based conservation strategy, the potential for a completely opportunistic design strategy to result in less effective NTZs highlights the challenges of such co-management regimes.

Specifically, stakeholders stressed the risk of poor NTZ site selection leading to poor results, in turn diminishing community support (S-4). This is especially relevant given the fact that a majority of fishers expected NTZs to benefit fishing production (Figure 3). Although NTZs have the potential to positively impact local fisheries $[10,41,42]$, few studies have found an empirical benefit to fishery yield from spatial closures. Thus, the complicated relationship between NTZs and fishery outcomes remains uncertain [2,9,43-47]. Given this uncertainty, it's potentially problematic that a majority of fishers expect NTZs to increase fishery production. While such expectations surely played a role in the fishers' decision to participate in the NTZ program, if not realized they also have the potential to result in disillusionment with the conservation process, distrust of management partners, or an eventual lack of compliance. Interestingly, although fishers expected production benefits from NTZs, they were reluctant to attribute much influence over perceived changes in production to NTZs (Table 2b). Thus, while fishers may have high expectations regarding the potential of NTZs to benefit fishing production, they remain skeptical of the realities of that potential.

Stakeholders agreed that in order for NTZs to succeed, managers must make clear the different objectives of the various NTZ sites (i.e. protect spawning aggregation sites, bolster lobster fishery, etc.) and be open about the experimental aspect of the process and willing to adapt sites if diagnostic data show poor results $(\mathrm{S}-4,6)$.

Stakeholders almost uniformly endorsed the NTZs' complementation of existing regulatory zoning within protected areas (Table 3). In the Mexican Caribbean, although over $97 \%$ of territorial waters are within designated MPAs, only $4 \%$ of this area is fully protected from fishing (COBI, unpublished data). NTZs 
were praised for increasing the area fully closed to fishing (S-4,5,6), an important contribution in a region where many marine protected areas exist as little more than legal concepts. Additionally, due to their status as fisheries management tools within protected areas, the NTZs grant multiple agencies some degree of enforcement authority, an important factor in a country whose enforcement agencies often lack the budget and priorities necessary for effective management (S$3,5)$.

\subsection{Community involvement and positive perceptions}

Fishers consistently demonstrated positive perceptions of the NTZs in their communities. Reflecting the strengths of the community-based model, fishers felt included in the decision-making process, participated in planning workshops, and knew and trusted their management partners (Figure 4). These are important findings given that many studies have shown front-end stakeholder input to be critical to increased stakeholder buy-in and ultimately to successful MPA management $[22,24,29]$. Notably, Velez et al. found during the 2011 NTZ design process that only $27 \%$ of fishers from SKBR cooperatives included in this study felt they knew their NTZ management partners, compared to $87 \%$ of such fishers interviewed here [18], demonstrating that managers' investment in sustained relationships has succeeded in building ties with the fishing community.

Stakeholders stressed the importance of the community-based management model in achieving and sustaining high levels of fisher support for NTZs (Table 3). A sustained presence in the community by scientists and managers, fisher input at all stages of the project, and environmental education initiatives were cited as factors engendering community support (S-1,2,3,4,5,6). Fishers praised their inclusion in the biological monitoring of NTZs: "They collaborate with the fishers themselves... They give training courses and hire us as divers...They take us to monitor [the NTZs] and we learn from them." (F-BCB). Similarly, stakeholders cited the importance of citizen-science biological monitoring in allowing fishers to directly observe benefits and in fostering ownership of the NTZ initiative $(S-5,6)$.

Near the end of the initial five-year NTZ term, fishers have expressed near unanimous support for NTZ renewal. Given the frustrations and poor management outcomes for BCBR NTZs described here, the support across all cooperatives for NTZ maintenance is surprising. The culture of support for NTZs, even in the face of management challenges and, in some cases, failures, represents a success for the comanagement strategy. It is clear that managers have succeeded in fostering the stakeholder investment that is often cited as the primary advantage of communitybased conservation initiatives.

\subsection{Challenges of enforcement}

Fishers and managers alike asserted that the greatest challenge facing the NTZs is a lack of enforcement and the illegal fishing thus engendered. It is important to note that poor enforcement is not a problem isolated to the NTZs, but rather a chronic problem across all protected areas in the region $(\mathrm{S}-2,6)$. A small and 
continuously decreasing budget has prevented the National Commission for Fisheries and Aquaculture (CONAPESCA), responsible for NTZ enforcement, from maintaining a presence in the protected areas (S-1,2,3,5,6). At the same time, representatives of the National Commission for Natural Protected Areas (CONANP) lack the authority to detain poachers or confiscate equipment $(S-1,5,6)$. Indeed, the absence of effective monitoring programs and poor coordination between government institutions have been identified as major challenges to Mexican coastal management [48]. Over the last decade, illegal fishing in the region has become increasingly organized, with poachers in possession of larger boats and faster motors than both cooperative fishers and authorities $(S-4,5)$. Further complicating enforcement, illegal fishing is often linked to drug-smuggling and organized crime, meaning poachers can be armed and community surveillance efforts often deteriorate in the face of intimidation and violence $(S-1,4,5)$.

Among fisher responses, it is clear and intuitive that levels of confidence in the NTZ enforcement system are inversely correlated with known instances of illegal fishing within NTZs (Figure 5a, Table 2a). In addition to eroding confidence in authorities, and potentially more troubling for managers, a lack of enforcement erodes support for existing NTZs: "Enforcement is terrible. What's the point if we stop fishing in these areas and the poachers keep coming?" (F-BCA). Similarly, ineffective enforcement decreases enthusiasm for future conservation measures: "If there were enforcement, we would have the confidence to say, 'OK, let's create more NTZs.' But without this trust, how are we going to do more?" (F-BCB). In fact, having observed illegal fishing within NTZs was loosely correlated with opposition to NTZ expansion (Pearson, $\mathrm{p}=0.0556$ ). Without proper enforcement, the creation of NTZs can be seen as handicapping rule-abiding cooperative fishers against poachers, increasing tension within the fishing community and the likelihood of broken compliance.

Encouragingly, although illegal fishing is present in SKBR and rampant in $\mathrm{BCBR}$, rates of illegal fishing by cooperative members are perceived to be low (Table 2a). While rates of cooperative poaching are self-reported and thus likely underestimates, the high level of compliance amongst cooperative fishermen represents a victory for the community-based management regime.

\subsection{Local context influences outcomes}

One of the most consistent trends identified is the disparity between NTZ reception in Sian Ka'an and Banco Chinchorro. Despite similarities in geography, fishery structure, fishing pressure, and NTZ implementation process, BCBR fishers consistently reported worse management outcomes than their SKBR counterparts, illustrating the importance of local context in influencing conservation success.

Management stakeholders implicated various factors in this discrepancy. Most importantly, illegal fishing is more prevalent and better organized in BCBR than in SKBR (S-1,3,4,5,6). Specifically, BCBR cooperatives currently operate the only legal L. gigas fishery in Quintana Roo. This high value fishery attracts a large poaching presence, and the failure of authorities to effectively regulate the fishery has angered cooperative fishers and soured the relationship between regulators and fishers $(S-4,6)$. 
Additionally, stakeholders pointed to differences in community organization and culture as factors contributing to differences in NTZ perception. SKBR cooperatives are older, have been involved in research and conservation initiatives for longer, and have a stronger working relationship with the protected area that encompasses their concessions than BCBR cooperatives (S-2,3). Strong individual leadership within the community and a robust internal organizational and regulatory framework were cited as advantages of the SKBR cooperatives (S-2), while community apathy and a lack of visionary leadership were seen as hindering the potential of BCBR cooperatives to take advantage of conservation initiatives ( $\mathrm{S}$ $1,3)$.

These findings reinforce the idea that considering local context is critical to management success [49]. Specifically, investing in sustained working relationships, building community organization and leadership, and tailoring enforcement strategies to local needs can improve community receptiveness to NTZ implementation.

\subsection{Evaluating NTZs within a fisheries resource management context}

The FRM model proposed by Nielsen and Holm and adapted here is well suited to modeling the Mexican Caribbean NTZs. By integrating multiple disciplinary repertoires relevant to FRM (social, biological, political, etc.), the framework allows for the identification and correction of different categories of failure (i.e. resource allocation, intervention, policy efficacy). This recognition of the multi-sectoral nature of fisheries management, as well as the acknowledgement of the social systems that drive fishing pressure, mirrors the community-based management style employed in Sian Ka'an and Banco Chinchorro.

Examining the fourth function of the FRM evaluative model, it is clear that much work remains on the policy making front, particularly concerning the uncoordinated structure of relevant governance agencies and the ability of authorities to enforce Mexican fisheries law. The community-based model of cooperation between government, NGOs, and fishers will continue to be tested by this challenging political landscape.

With the goal of adaptive NTZ management predicated on systemic learning, (i.e. the FRM system's ability to detect and correct management error), the cyclical and iterative nature of the framework becomes imperative. Indeed, the legal renovation structure of the NTZs discussed here facilitates an iterative, adaptive approach to management. If the initial five-year NTZ term is viewed as the first turn of the FRM cycle (Figure 2), then managers must now prepare for and initiate the second. They must continue to inform their decisions through scientifically sound diagnostics such as biological monitoring and assessments of the perceptions of involved fishing communities, and should adapt their objectives based on diagnostic results and a constantly changing local context. Most importantly, effective adaptive management will require the tailoring of intervention strategy according to the cumulative knowledge attained during the previous five-year cycle. 


\section{Final considerations}

This work shows the community-based NTZ management strategy to have inherent tradeoffs. The benefits of sustained community support must be weighed against the potential to protect sites of limited biological value. Community surveillance and enforcement, while effective in maintaining cooperative compliance, fail in the face of organized poaching and weak regulation. Through sustained working relationships and information flow, as well as the provision of diversified training and income opportunities to fishers, managers have succeeded in fostering the community support sought through co-management. That support, however, is contingent upon authorities complying with their part of the agreement, namely effective surveillance. Unfortunately, this remains an enormous challenge given the complicated and uncoordinated governance context in the Mexican Caribbean.

Finally, it is important to remember that conservation is a long process. Just five years into the NTZ program, it is difficult to declare outright successes or failures. Rather, the initiative should be viewed through the long lens of constant adaptation. In November 2017, the northern SKBR NTZs were legally renewed for an additional five-year term, representing both a success for managers and an opportunity to improve management through careful evaluation and adaptation. Employing and building upon heuristic models such as the basic FRM framework discussed here can facilitate these processes. Managers must be open and honest about the current realities of the NTZs, and strive to continually adapt them according to local context and continued biophysical and socioeconomic diagnostics. The community-based NTZ should be understood as an inherently imperfect model, but one capable, with invested and adaptive management, of sustained application in diverse communities.

\section{Acknowledgements}

This work was supported by the U.S. Fulbright Program and the Comisión México-Estados Unidos para el Intercambio Educativo y Cultural (COMEXUS), with additional fieldwork funding generously provided by Summit Foundation, Oak Foundation, and the Walton Family Foundation. We are grateful to the fishing communities of Sian Ka'an and Banco Chinchorro for their participation, and to the involved NGO representatives, researchers, and government officials for their insights. We would also like to thank Inés López-Ercilla and Jorge Torre for their thoughtful and constructive feedback. 


\section{References}

[1] IUCN World Commission on Protected Areas (IUCN-WCPA) (2008). Establishing Marine Protected Area Networks - Making It Happen. Washington, D.C.: IUCN-WCPA, National Oceanic and

Atmospheric Administration and The Nature Conservancy. 118 p.

[2] Pita C, Pierce GJ, Theodossiou I, Macpherson K (2011) An overview of commercial fishers' attitudes towards marine protected areas. Hydrobiologia 670: 289-306.

[3] Agardy T, Bridgewater P, Crosby M, Day J, Dayton PK, Kenchington R, Laffoley D, McConney P, Murray PA, Parks JE, and Peau L (2003) Dangerous targets? Unresolved issues and ideological classes around marine protected areas. Aquatic Conservation: Marine and Freshwater Ecosystems 13: 353367.

[4] Rife AN, Erisman B, Sanchez A, and Aburto-Oropeza O (2012) When good intentions are not enough...Insights on networks of "paper park" marine protected areas. Conservation Letters 00: 1-13

[5] Rife AN, Aburto-Oropeza O, Hastings P, Erisman B, Ballantyne F, Wielgus J, Sala E, and Gerber L (2013) Long-term effectiveness of a multi-use marine protected area on reef assembleges and fisheries landings. Journal of Environmental Management 117: 276-283.

[6] Sala E and Giakoumi S (2017) No-take marine reserves are the most effective protected areas in the ocean. ICES Journal of Marine Science.

[7] Halpern BS (2003) The Impact of Marine Reserves: Do Reserves Work and Does Reserve Size Matter? Ecological Applications 13: S117-S137.

[8] Lester SE, Halpern BS, Grorud-Colvert K, Lubchenco J, Ruttenberg BI, Gaines SD, Airamé S, and Warner RR (2009) Biological effects within no-take marine reserves: a global synthesis. Marine Ecology Progress Series 384: 33-46.

[9] Sale PF, Cowen RK, Danilowicz BS, Jones GP, Kritzer JP, Lineman KC, Planes S, Polunin NV, Russ GR, Sadovy YJ, and Steneck RS (2005) Critical science gaps impede use of no-take fishery reserves. Trends in Ecology and Evolution 20: 74-80.

[10] Vandeperre F, Higgins RM, Sánchez-Meca J, Maynou F, Goñi R, Martín-Sosa P, Pérez-Ruzafa A, Afonso P, Bertocci I, Crec'hriou R, D’Anna G, Dimech M, Dorta C, Esparza O, Falcón JM, Forcada A, Guala I, Direach LL, Marcos C, Ojeda-Martínez C, Pipitone C, Schembri PJ, Stelzenmüller V, Stobart B, and Santos RS (2011) Effects of no-take area size and age of marine protected areas on fisheries yields: a meta-analytical approach. Fish and Fisheries 12: 412-426.

[11] Berkes F (2004) Rethinking Community-Based Conservation. Conservation Biology, 18: 621-630.

[12] Cinner JE, McClanahan TR, MacNeil MA Graham NAJ, Daw TM, Mukminin A, Feary DA,

Rabearisoa AL, Wamukota A, Jiddawi N, Campbell SJ, Baird AH, Januchowski-Hartley FA, Hamed S, Lahari R, Morove T, and Kuange J (2012) Comanagement of coral reef social-ecological systems.

Proceedings of the National Academy of Sciences 109: 5219-5222.

[13] Gelcich S, Godoy N, and Castilla JC (2009) Artisanal fishers' perceptions regarding coastal comanagement policies in Chile and their potentials to scale-up marine biodiversity conservation. Ocean and Coastal Management 52: 424-432.

[14] Brooks JS, Waylen KA, and Mulder MB (2012) How national context, project design, and local community characteristics influence success in community-based conservation projects. PNAS 109: 21265-21270.

[15] Brosius JP, Tsing AL, and Zerner C (1998) Representing communities: Histories and politics of community-based natural resource management. Society and Natural Resources 11: 157-168.

[16] Jones PJS (2009) Equity, justice and power issues raised by no-take marine protected area proposals. Marine Policy 33: 759-765.

[17] De Santo EM (2013) Missing marine protected area (MPA) targets: How the push for quantity over quality undermines sustainability and social justice. Journal of Environmental Management 124: 137-146.

[18] Velez M, Adlerstein S, and Wondolleck J (2014) Fishers' perceptions, facilitating factors and challenges of community-based no-take zones in the Sian Ka'an Biosphere Reserve, Quintana Roo, Mexico. Marine Policy 45: 171-181. 
[19] Ferse SCA, Máñez Costa M, Schwerdtner Mañez K, Adhuri DS, and Glaser M (2010) Allies, not aliens: increasing the role of local communities in marine protected area implementation. Environmental Conservation 37: 23-34.

[20] Fulton S, Hernández-Velasco A, Suarez-Castillo A, Fernández-Rivera Melo F, Rojo M, SáenzArroyo A, Weaver AH, Cudney-Bueno R, Micheli F, and Torre J (2017) From fishing fish to fishing data: The role of artisanal fishers in conservation and resource management. Manuscript in preparation.

[21] Charles A and Wilson L (2008) Human Dimensions of Marine Protected Areas. ICES Journal of Marine Science 66: 6-15.

[22] Pomeroy, RS, Parks JE and Watson LM (2004). How is Your MPA Doing? A Guidebook: Biophysical, socioeconomic and governance indicators for the evaluation of management effectiveness of marine protected areas. IUCN World Commission on Protected Areas- Marine, World Wide Fund for Nature, and National Oceanographic and Atmospheric Administration. Gland, Switzerland and Silver Spring, Maryland.

[23] Christie P (2004) Marine Protected Areas as Biological Successes and Social Failures in Southeast Asia. American Fisheries Society Symposium 42: 155-164.

[24] Himes AH (2007) Performance indicators in MPA management: Using questionnaires to analyze stakeholder preferences. Ocean and Coastal Management 50: 329-351.

[25] Pollnac RB, Crawford BR, and Gorospe MLG (2001) Discovering factors that influence the success of community0based marine protected areas in the Visayas, Philippines. Ocean and Coastal Management 44: 683-710.

[26] Himes AH (2003) Small-Scale Sicilian Fisheries: Opinions of Artisanal Fishers and Sociocultural Effects in Two MPA Case Studies. Coastal Management 31: 389-408.

[27] Suuronen P, Jounela P, and Tschernij V (2010) Fishermen responses on marine protected areas in the Baltic cod fishery. Marine Policy 34: 237-243.

[28] Bennett NJ (2015) Using perceptions as evidence to improve conservation and environmental management. Conservation Biology 30: 582-592

[29] Suman D, Shivlani M, and Milon JW (1999) Perceptions and attitudes regarding marine reserves: a comparison of stakeholder groups in the Florida Keys National Marine Sanctuary. Ocean and Coastal Management 42: 1019-1040.

[30] Leleu K, Alban F, Pelletier D, Charbonnei E, Letourneur Y, and Boudouresque CF (2012) Fishers' perceptions as indicators of the performance of Marine Protected Areas (MPAs). Marine Policy 36: 414-422.

[31] McCay BJ, Micheli F, Ponce-Díaz G, Murray G, Shester G, Ramirez-Sanchez S, and Weisman W (2014) Cooperatives, concessions, and co-management on the Pacific coast of Mexico. Marine Policy 44: 49-59.

[32] Briones-Fourzán P, Lozano-Álvarez E (2000) The spiny lobster fisheries in Mexico. In: Phillips BF, Kittaka J (Eds.) Spiny Lobsters: Fisheries and Culture (2nd edition). Fishing News Books (Blackwell), Oxford, pp. 169-188.

[33] Sosa-Cordero E, Liceaga-Correa MLA, and Seijo JC (2008) The Punta Allen lobster fishery: current status and recent trends. Case studies in fisheries self-governance: 149-162.

[34] Lillo JC, Provencio E, Elvira JM, Carbonell DG, Cruz MG, and Luhrs TC (2000) Programa de Manejo de la Reserva de la Biosfera Banco Chinchorro. Instituto Nacional de Ecología, México City, México

[35] Moreno A, Bourillón L, Flores E, and Fulton S (2016) Fostering fisheries management efficiency through collaboration networks: the case of the Kanan Kay Alliance in the Mexican Caribbean. Bulletin of Marine Science 92.

[36] Nielsen KN and Holm P (2007) A brief catalogue of failures: Framing evaluation and learning in fisheries resource management. Marine Policy 31: 669-680.

[37] Stuckey HL (2013) Three types of interviews: Qualitative research methods in social health. Journal of Social Health and Diabetes 1: 56-59.

[38] Ervin J (2003) Protected Area Assessments in Perspective. BioScience 53: 819-822.

[39] Fulton S, Caamal J, and Marcos, S (2015) Resultados del Monitoreo de Biodiversidad en los Refugios Pesqueros de Quintana Roo, 2012-2015. Comunidad y Biodiversidad A.C. Guaymas, Sonora, México. 
[40] Fulton S, Caamal J, Marcos S, Goldman N, Canto Noh JA, Catzim Pech P, Sulub Castro H, Catzim Azcorra MF, and Ayer A (2017) Resultados de Monitoreo en la Red de Zonas de Refugio Pesquero de la S.C.P.P. Cozumel, 2012-2016. Comunidad y Biodiversidad A.C. Guaymas, Sonora, México.

[41] Alcala AC, Russ GR, Maypa AP, and Calumpong HP (2005) A long-term, spatially replicated experimental test of the effect of marine reserves on local fish yields. Canadian Journal of Fisheries and Aquatic Sciences 62: 98-108.

[42] Russ GR, Alcala AC, Maypa AP, Calumpong HP, and White AT (2004) Marine Reserve Benefits Local Fisheries. Ecological Applications 14: 597-606.

[43] Hilborn R, Stokes K, Maquire J, Smith T, Botsford LW, Mangel M, Orensanz J, Parma A, Rice J, Bell J, Cochrane KL, Garcia S, Hall SJ, Kirkwood GP, Sainsbury K, Steffansson G, Walters C (2004) When can marine reserves improve fisheries management? Ocean and Coastal Management 47: 197-205.

[44] Jones PJS (2002) Marine protected area strategies: issues, divergences and the search for middle ground. Reviews in Fish Biology and Fisheries 11: 197-216.

[45] Kaiser MJ (2005) Are marine protected areas a red herring or fisheries panacea? Canadian Journal of Fisheries and Aquatic Sciences 62: 1194-1119.

[46] Norse EA, Grimes CB, Ralston S, Hilborn R, Carlos J, Palumbi SR, Fraser D, and Kareiva P (2003) Marine Reserves: The Best Option for Our Oceans? Frontiers in Ecology and the Environment 1: 495502.

[47] Polunin NVC (2002). Handbook of fish and fisheries, vol. II. Oxford, UK: Blackwell Science. [48] Nava Fuentes JC, Granados PA, and Martins FC (2017) Coastal management in Mexico: Improvements after the marine and coastal policy publication. Ocean and Coastal Management 137: 131-143.

[49] Waylen KA, Fischer A, McGowan PJK, Thirgood SJ, and Milner-Gulland EJ (2010) Effect of Local Cultural Context on the Success of Community-Based Conservation Interventions. Conservation Biology 24: 1119-1129. 